\title{
The Role of Culture, Language and Trade Agreements in Global Wine Trade
}

\author{
Jeremiás Máté Balogh, Attila Jámbor \\ Corvinus University of Budapest, Hungary
}

\begin{abstract}
In the progressively globalising world, wine trade is changing shape. In recent decades, major wine producers have suffered a remarkable drop in their domestic wine consumption, while New World wine producers have increased their production potential and induced new demand in foreign markets. These changes have been accompanied by a geographical relocation of wine consumption and trade. The aim of our paper is to analyse the effect of cultural-geographical proximity, free trade and the role of linguistic similarity on bilateral wine trade in the world major wine producer countries, employing balanced panel gravity model. Regression results suggest that larger countries export more wine, while transport costs increase in line with geographical distance, especially for landlocked trading partners. Moreover, global wine export costs are lower if trading partners are culturally similar; have the same religion or both are members of the WTO or have regional trade agreements.
\end{abstract}

\section{Keywords}

Wine trade, cultural proximity, language clusters, gravity model.

Balogh, J. M. and Jámbor, A. (2018) "The Role of Culture, Language and Trade Agreements in Global Wine Trade", AGRIS on-line Papers in Economics and Informatics, Vol. 10, No. 3, pp. 17-29. ISSN 1804-1930. DOI 10.7160/aol.2018.100302.

\section{Introduction}

In the last century, global wine market has progressively been developed. Approximately one million winemakers are producing around 3 billion cases of wine each year (Stanley, 2013) at the global level. The international demand for wine is rising year by year and the world wine industry has also changed to a great extent.

However, European traditional wine producers such as France, Italy and Spain have suffered a remarkable drop in their domestic wine consumption since the 1980s, mainly due to changing wine policy regulations, while New World wine producers have increased their production potential and induced new demand in foreign markets (Cembalo et al., 2014). Consequently, the USA, Australia, Chile, New Zealand, and South Africa have gained increasing market shares both in volumes and in values exported (Morrison and Rabellotti, 2014) in the global wine market.

These changes have been accompanied by a geographical relocation of demand (Aizenman and Brooks, 2008), creating new challenges and opportunities for international trade. To date, almost half of the wines are consumed outside of a country of production that is rarely associated with an extra trade cost (Dal Bianco et al., 2015).

Consequently, the objective of our paper is to investigate the factors influencing international trade among the major global wine market players and their trading partners as well as to reveal the cultural-linguistic factors behind wine trade flows.

According to Tinbergen (1962), the size of bilateral trade flows can be approximated by the so-called “gravity equation", mimicking Newton's famous gravity theory. The gravity equation provides evidence for the relationship between the size of economies, the distance between them and the number of products traded.

There are a number of research dealing with international wine trade using gravity equation models (Pinilla and Serrano 2008, Dascal et al., 2002, De Blasi et al., 2007, Dal Bianco et al., 2013; 2015, Lombardi et al., 2016). However, these models are generally using the basic model with common variables. In this paper, we aim 
to use a more sophisticated model as we are especially interested in the effect of cultural and geographical variables as well as language clusters on bilateral wine trade of major global wine producer countries.

We estimate the standard gravity equation for the analysis and employ several different estimation methods such as OLS, Random Effects, Pseudo Poisson Maximum Likelihood (PPML) and Heckman two-stage approach suggested by the literature in order to estimate the gravity regression for the wine trade.

The aim of our paper is to analyse the effect of cultural-geographical proximity, free trade and the role of linguistic similarity on bilateral wine trade in the world major wine producer countries, employing balanced panel gravity model.

In doing so, the paper is structured as follows. The first section describes the theoretical background behind gravity models, including its application to the wine trade, followed by the demonstration of our methods used. The fourth section shows our econometric specification, followed by the discussion of the results. The last section concludes.

\section{Materials and methods}

Gravity models have been used to refer to a variety of different specifications to determine bilateral trade flows and estimate factors influencing trade costs. A number of slightly different specifications of the gravity equation exist in the trade literature. Moreover, the gravity equation can be derived from several theory-consistent estimation methods.

Most of the gravity models work with a single factor of production, factor income and hence Gross Domestic Products (GDP). Gravity models can be divided into the category of "demand-side" or "supply-side" derivations (Head and Mayer, 2013). The earliest modern application of the gravity equation for trade was made by Anderson (1979). The gravity equation is based on standard symmetric Dixit-Stiglitz-Krugman monopolistic competition assumptions derived by multiple authors. It assumes that each country has firms supplying one variety to the world from a home-country production site. Utility features a constant elasticity of substitution between all varieties available in the world (Head and Mayer, 2013). Eaton and Kortum (2002) derive a gravity equation from the constant elasticity of substitution based on the approaches in approximately every respect and the results they obtain show a remarkable similarity. According to Bergstrand $(1985,1989)$, the gravity model is a direct implication of the monopolistic competition model of Paul Krugman (1980). Helpman et al. (2008) and Chaney (2008) obtained gravity model from a theoretical model of international trade in differentiated goods with firm heterogeneity.

Only a limited number of articles are available in international trade literature that investigates wine trade by gravity equation models concerning the European Union or South American wine trade.

Pinilla and Serrano (2008) analysed the longterm determinants of Spanish table wine exports by gravity panel data estimation technique between 1871 and 1935. The results of their model showed that Spanish table wine was exported to countries with large growing markets that were close both culturally and geographically.

Dascal et al. (2002) employed a gravity model approach in order to analyse the main factors affecting the trade flows of wine in EU-12 countries for the period 1989-1997. Their results revealed that wine trade was positively influenced by an increase of GDP per capita, since greater income promotes trade.

De Blasi et al. (2007) examined the magnitude of trade flows for high quality wine from Italy to its main importing countries analysed by the gravity model. They concluded that the enlargement of the EU provided better opportunities for high quality Italian wine exporters.

Dal Bianco et al. (2013) analysed the Argentinean wine industry also by using the gravity model. They concluded that wine flows can be basically explained by the importer countries' economic and political characteristics. In addition, the lack of free trade agreements with the European Union and North America revealed a significant weakness for Argentinean wineries.

Dal Bianco et al. (2015) investigated the impact of trade barriers on the world wine trade focusing on trade costs impeding exports, including transport, tariffs, technical barriers and sanitary and phytosanitary standards. Their gravity model was estimated using data from the main importing and exporting countries between 1997 and 2010 . Their results identify which regulations can adversely affect trade providing useful information to policy-makers involved in negotiations on trade frictions.

Lombardi et al. (2016) analysed the intra-EU trade of the world's major wine exporters such as Italy, 
France, and Spain employing augmented version of the gravity model. They took into account effects of transportation costs, as well as demand and supply gaps between origin and destination countries, on the size of bilateral trade flows.

However, these studies analysed only a region or a part of the world wine trade and they did not take into account the wine trade of the major world wine exporter countries. In addition, the effect of cultural similarity on wine trade has not yet been investigated either.

We employ a standard gravity model for a sample of world wine trade. The standard formula of gravity equation can be calculated as follows (Anderson and van Wincoop's, 2003):

$$
X_{i j}=G * S_{i} * M_{j} * \varphi_{i j}
$$

where $X_{i j}$ is the value of exports from $\mathrm{i}$ to $\mathrm{j}$,

$M_{j}$ denotes importing country's GDP,

$S_{i}$ comprises exporter's GDP,

$G$ is a variable that does not depend on $\mathrm{i}$ or $\mathrm{j}$ such as the level of world liberalization,

$\varphi_{i j}$ represents the ease of exporter $\mathrm{i}$ to access the market of $\mathrm{j}$.

The log-linear model of gravity equation can be calculated by taking the natural logarithms of these variables (Bacchetta et al., 2012):

$$
\ln X_{i j}=\ln G+\ln S_{i}+\ln M_{j}+\ln \varphi_{i j}
$$

A number of variables are generally used to capture trade costs such as bilateral distance, islandslandlocked countries, common borders, common language or cultural features such as colonial history, common religion that are usually thought to be stable over time (Bacchetta et al., 2012).

As culture shifts over time, it may change more when countries are more exposed to international trade - therefore, it is important to consider culture-based measures (Head and Mayer, 2013). In addition, trade costs are probably lower for countries whose have a common language or other relevant cultural character because they are likely to know more about each other and understand better each other's culture or business practices (Bacchetta et al., 2012).

Sharing a religion has also been shown to raise trade (Kang and Fratianni 2006, Linders and de Groot 2006). Religious similarity is a variable created from data on religion by La Porta et al. (1999), who provide the percentage of a country's residents identified as Catholic, Protestant, Muslim, or Other.

The relationship between physical and cultural distance also deserves attention in gravity models. Countries tend to group together geographically because culture spreads first to those areas nearest to its origin (Ronen and Shenkar, 1985).

However, cultural proximity and geographic proximity are not necessarily related. Three countries pertaining to the Anglo-Saxon cluster such as Australia, the UK, and the United States are located in three different continents due to colonization and immigration (Ronen and Shenkar, 1985).

To measure cultural distance between the home and the host country, Ronen and Shenkar (1985) and Triandis (1994) clustered countries based on their relative similarities along four different dimensions, i.e., language, geography, wealth, and religion. In addition, Ronen and Shenkar synthesize eight previous studies that classify countries according to aspects such as prevalent needs, values, and work attitudes. We used clusters of countries that present similar cultural characteristics to home country by the work of Filippaios and Rama (2011).

Tariff barriers are also generally included in the form of dummies for the existence of regional trade agreements (RTAs) or use of WTO membership.

Literature suggests several ways to estimate gravity models from linear pooled OLS to nonlinear PPML. The standard gravity equation and other multiplicative models (such as the Cobb-Douglas production function) can be estimated with OLS. However, Santos and Tenreyro (2006) found many problems of this simple approach and argued that Pseudo-Poisson maximum likelihood (PPML) was a smart alternative to linear-in-logs OLS for multiplicative models like the gravity equation. A useful feature of the PPML is that it permits the inclusion of zero trade values as well. In this paper, we employ heteroscedasticity robust panel estimation, including zero trade flows and countrytime fixed effects for bilateral wine export.

Based on the empirical evidence of wine gravity literature the following hypotheses are tested here:

H1: The standard gravity model can be applied to world wine trade.

Standard gravity models generally argue that bilateral trade is inversely related to geographical distance, e.g. trade volumes decrease with distance. 
However, it is also interesting to analyse how geographical distance is related to the costs of trade, especially in the case of a landlocked country. This situation makes trade cost higher because sea access enables water transport to reduce costs (Bacchetta et al., 2012). We employ simple distance of most populated cities in $\mathrm{km}$ as a proxy for geographical distance, while we use a dummy variable for landlocked countries. Data come from the CEPII database and a positive relationship is expected.

H2: Culturally similar countries trade more wine.

Lower trade barriers stimulate trade by reducing trade costs (Bacchetta et al., 2012, p. 106). We test this argument for wine trade by using proxies for cultural similarities like the common language, past colonial history or common religion, available at the CEPII database. Again, a positive relationship is expected.

H3: Members of the same language cluster will trade more wine with each other.

It seems to be evident that a common language generally makes trade easier. This assumption is tested here by using the language clusters available in the CEPII database. A religion variable derived from data of La Porta et al. (1999). To measure the cultural distance between the home and the host country, we employed language classification variables (see Appendix 1) from the work of Ronen and Shenkar (1985) in Filippaios and Rama (2011). A positive relationship is expected, too.

H4: Trade agreements encourage global wine trade.

The liberalisation of global wine trade leads to a higher number of different quality wines available on shelves. Here we test whether this relationship holds for all the major wine exporter countries. A dummy variable is used for WTO membership and the existence of regional trade agreements between trading partners. Information on WTO membership can be found on the WTO website (WTO, 2013). Data on the regional trade agreement (RTA) variable comes from International Economics Data and Programs of José de Sousa (De Sousa, 2014). We expect to have a positive relationship here.

Our strongly balanced panel dataset includes bilateral trade data of 32 considerable wine exporter countries and their 216 trading partners (Appendix 2) between 2000-2012, giving 48802 observations. The dependent variable of the model comes from bilateral wine export data of the World Bank World Integrated Trade Solution (WITS) database in HS-6 level, for product code 2204: wine of fresh grapes, including fortified wines; grape must (World Bank, 2014a). Table 1 summarises all the variables used.

We employ four different estimation methods: pooled OLS and Random Effects suggested by Baier and Bergstrand (2009), PPML by Santos and Tenreyro (2006) and the Heckman two-stage approach (Heckman, 1979). In all models, country fixed effect are included by country-pairs and time fixed effects by year dummies. To avoid dropping zero trade values by using logarithm form, we added a small value of 1 dollar to zero trade flows. The following models were estimated (note that in PPML models wine export are used in levels instead of the logarithm form):

In wine export $_{i j}=\alpha+\beta_{l} \ln$ GDPexp $_{i}+\beta_{2} \ln$ GDPimp $_{j}$ $+\beta_{3}$ lndist $_{i j}{ }+\beta_{4}$ comlang_off $_{i j}+\beta_{5}$ comcol $_{i j}$ $+\beta_{6}$ colony $_{i j}+\beta_{7}$ religion $+\beta_{8}$ landlocked $_{i j}+\beta_{9}$ WTO $_{i j}$ $+\beta_{10} R T A_{i j}+D_{i} \exp$ dummies $_{i}+D_{j}$ imp dummies $+D_{i}$ time dummies $_{i j}+u i j$

ln wine exportij $=\alpha+\beta_{1} \ln G D P \exp _{i}+\beta_{2} \ln$ GDPimp $+\beta_{3}$ lndist $_{i j}+\beta_{4}$ comlang_off $_{i j}+\beta_{5}$ comcol $_{i j}$ $+\beta_{6}$ colony $_{i j}+\beta_{7}$ religion $+\beta_{8}$ landlocked $_{i j}$ $+\beta_{9} W_{i j}+\beta_{10} R T A_{i j}+\beta_{11}$ Anglo-saxon $_{i j}$ $+\beta_{12}$ Germanic $_{i j}+\beta_{13}$ LatinAm $_{i j}+\beta_{14}$ LatinEU $_{i j}$ $+D_{i} \exp$ dummies $_{i}+D_{j} \quad$ imp dummies $_{j}$

$+D_{i}$ time dummies $_{i j}+u_{i j}$

In wine export $_{i j}=\alpha+\beta_{1} \ln$ GDPexp $_{i}+\beta_{2} \ln$ GDPimp $_{j}$ $+\beta_{3}$ lndist $_{i j}+\beta_{4}$ comcol $_{i j}+\beta_{5}$ colony $_{i j}+\beta_{6}$ religion $+\beta_{7}$ landlocked $_{i j}+\beta_{8}$ WTO $_{i j}+\beta_{9}$ RTA $_{i j}$ $+\beta_{10}$ Anglo-saxon $_{i j}+\beta 11$ Germanicij $+\beta_{12}$ LatinAm $_{i j}$ $+\beta_{13}$ LatinE $_{i j}+D_{i} \exp _{\text {dummies }}+D_{j}$ imp dummies $_{j}$

$+D_{i}$ time dummies $_{i j}+u_{i j}$ 


\begin{tabular}{|c|c|c|c|}
\hline Independent variables & Description & Data sources & Exp. sign \\
\hline $\operatorname{lnGDPexp}$ & GDP of wine exporter (GDP in current US dollar) & World Bank (2014b) & + \\
\hline lnGDPimp & GDP of wine importer (GDP in current US dollar) & World Bank (2014b) & + \\
\hline lndist & distance: simple distance of most populated cities in $\mathrm{km}$ & CEPII (2013) & - \\
\hline $\begin{array}{l}\text { Independent dummy } \\
\text { variables }\end{array}$ & Description & Data sources & Exp. sign \\
\hline comlang_off & $\begin{array}{l}\text { common official language: } 1 \text { if trader countries have common } \\
\text { official primary language, } 0 \text { otherwise }\end{array}$ & CEPII (2013) & + \\
\hline comcol & $\begin{array}{l}\text { common colonizer: } 1 \text { for common colonizer post } 1945 \text {, } \\
0 \text { otherwise }\end{array}$ & CEPII (2013) & + \\
\hline colony & 1 if traders were ever in colonial relationship, 0 otherwise & CEPII (2013) & + \\
\hline landlocked & $\begin{array}{l}\text { landlocked country: } 1 \text { if both traders are landlocked, } \\
0 \text { otherwise }\end{array}$ & CEPII (2013) & - \\
\hline religion & 1 if common main religion for both countries, 0 otherwise & La Porta et al. (1999) & + \\
\hline RTA & 1 if traders have regional trade agreements, 0 otherwise & José de Sousa (2014) & + \\
\hline WTO & WTO: 1 if both traders are member of WTO, 0 otherwise & WTO (2013) & + \\
\hline $\begin{array}{l}\text { Language } \\
\text { classification }\end{array}$ & Description & Data sources & Exp. sign \\
\hline Anglo-Saxon & $\begin{array}{l}1 \text { if trader countries belonging to Anglo-Saxon cluster, } \\
0 \text { otherwise (Filippaios and Rama 2011) }\end{array}$ & $\begin{array}{l}\text { Ronen and Shenkar } \\
(1985)\end{array}$ & + \\
\hline Germanic & $\begin{array}{l}1 \text { if trader countries belonging to Anglo-Saxon cluster, } \\
0 \text { otherwise (Filippaios and Rama 2011) }\end{array}$ & $\begin{array}{l}\text { Ronen and Shenkar } \\
\qquad(1985)\end{array}$ & + \\
\hline Latin American & $\begin{array}{l}1 \text { if trader countries belonging to Latin American cluster, } \\
0 \text { otherwise (Filippaios and Rama 2011) }\end{array}$ & $\begin{array}{l}\text { Ronen and Shenkar } \\
\qquad(1985)\end{array}$ & + \\
\hline Latin European & $\begin{array}{l}1 \text { if trader countries belonging to Latin European cluster, } \\
0 \text { otherwise (Filippaios and Rama 2011) }\end{array}$ & $\begin{array}{c}\text { Ronen and Shenkar } \\
(1985)\end{array}$ & + \\
\hline
\end{tabular}

Source: own composition

Table 1: Description of independent variables.

\section{Results and discussion}

Table 2 summarises the results obtained by OLS and random effect estimations. The majority of the variables are highly significant. Regarding the first hypothesis, the common general gravity model applies for global wine trade with positive values for GDP and negative ones for distance. This means that economically bigger countries trade more with each other and as usual, distance and trade values are negatively related. According to our results, this also holds for our sample, meaning that distance discourages global wine trade.

As to the second hypothesis, cultural similarity seems to have a positive impact on wine trade in both models as expected. In other words, countries having similar cultural backgrounds trade more wine compared to those with different cultural background. However, language cluster results do not appear to be evident as just the Latin American cluster provides positive and significant results, questioning the original hypothesis.

Last but not least, the effects of regional trade agreements are positive and significant in the OLS model but not in the RE model. This is especially important in times when the role of free trade agreements has continuously been increasing. It seems that wine has been more traded regionally than globally. Generally, our results are in line with the literature except for language clusters.

Results obtained by the PPML estimation are summarised in Table 3 and they are consistent with the OLS model results described above. However, the PPML models highly confirm a positive role of language clusters and less trading costs between Anglo-Saxon, Germanic, Latin American and Latin European countries, supporting our third hypothesis. In other words, countries speaking similar languages tend to have traded more wine between 2000 and 2012 than those speaking a different language. Moreover, it seems that similar languages are also associated with less trade costs. The additional effect of language clusters (PPML model 2) reveals that in the case of Latin American countries, trade effect is the highest in line with OLS and random effect models. 


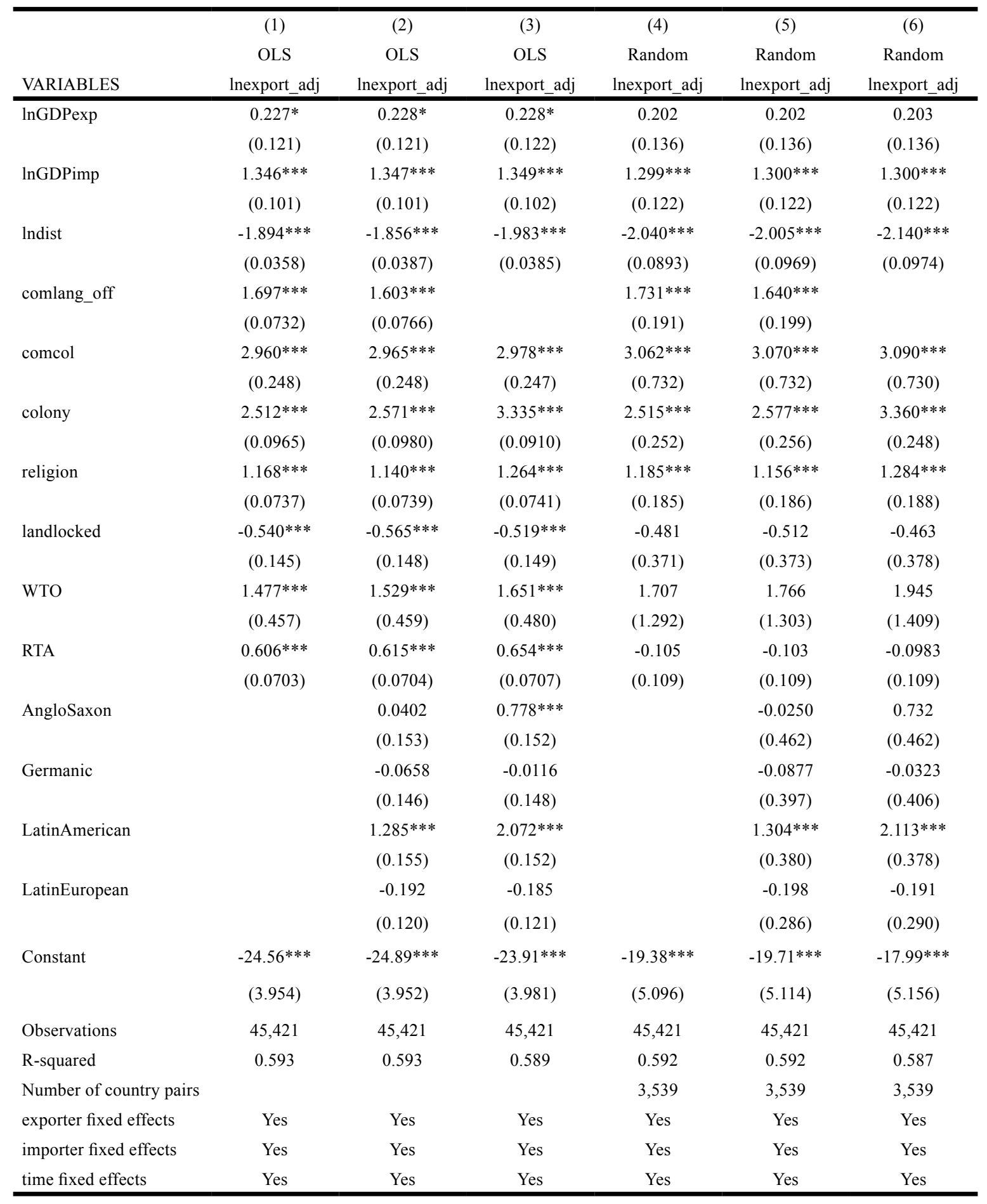

Note: to avoid dropping zero trade flows lnexport adj was calculated by adding 1 USD to 0 trade values.

Robust standard errors in parentheses; $* * * \mathrm{p}<0.01, * * \mathrm{p}<0.05, * \mathrm{p}<0.1$

Source: own calculation based on Word Bank (2014a, 2014b), CEPII (2013), De Sousa (2014), La Porta et al. (1999), Filippaios and Rama (2011) and WTO (2013) databases

Table 2: Results of OLS and Random effects estimation. 


\begin{tabular}{|c|c|c|c|}
\hline VARIABLES & $\begin{array}{c}\text { (1) } \\
\text { PPML } \\
\text { exportvalue }\end{array}$ & $\begin{array}{c}\text { (2) } \\
\text { PPML } \\
\text { exportvalue }\end{array}$ & $\begin{array}{c}\text { (3) } \\
\text { PPML } \\
\text { exportvalue }\end{array}$ \\
\hline $\operatorname{lnGDPexp}$ & $\begin{array}{c}0.152 \\
(0.187)\end{array}$ & $\begin{array}{c}0.156 \\
(0.184)\end{array}$ & $\begin{array}{c}0.167 \\
(0.186)\end{array}$ \\
\hline lnGDPimp & $\begin{array}{c}0.948 * * * \\
(0.179)\end{array}$ & $\begin{array}{c}0.949 * * * \\
(0.179)\end{array}$ & $\begin{array}{c}0.949 * * * \\
(0.179)\end{array}$ \\
\hline lndist & $\begin{array}{c}-0.352 * * * \\
(0.0828)\end{array}$ & $\begin{array}{c}-0.330 * * * \\
(0.0879)\end{array}$ & $\begin{array}{c}-0.375 * * * \\
(0.0843)\end{array}$ \\
\hline comlang_off & $\begin{array}{c}0.763 * * * \\
(0.153)\end{array}$ & $\begin{array}{c}0.561 * * * \\
(0.185)\end{array}$ & \\
\hline comcol & $\begin{array}{c}2.886^{* * *} \\
(0.801)\end{array}$ & $\begin{array}{c}2.996 * * * \\
(0.830)\end{array}$ & $\begin{array}{c}2.973 * * * \\
(0.772)\end{array}$ \\
\hline colony & $\begin{array}{c}0.514 * * \\
(0.239)\end{array}$ & $\begin{array}{c}0.520^{* *} \\
(0.243)\end{array}$ & $\begin{array}{c}0.672 * * * \\
(0.236)\end{array}$ \\
\hline religion & $\begin{array}{c}0.650 * * \\
(0.261)\end{array}$ & $\begin{array}{c}0.573 * * \\
(0.279)\end{array}$ & $\begin{array}{c}0.636^{* *} \\
(0.259)\end{array}$ \\
\hline landlocked & $\begin{array}{c}-1.341 * * \\
(0.547)\end{array}$ & $\begin{array}{l}-0.879 \\
(0.607)\end{array}$ & $\begin{array}{l}-0.584 \\
(0.628)\end{array}$ \\
\hline WTO & $\begin{array}{c}2.512 * * * \\
(0.855)\end{array}$ & $\begin{array}{c}2.503 * * * \\
(0.882)\end{array}$ & $\begin{array}{c}2.494 * * * \\
(0.922)\end{array}$ \\
\hline RTA & $\begin{array}{c}0.441^{* *} \\
(0.202)\end{array}$ & $\begin{array}{c}0.425^{* *} \\
(0.200)\end{array}$ & $\begin{array}{c}0.440 * * \\
(0.194)\end{array}$ \\
\hline AngloSaxon & & $\begin{array}{c}0.344 \\
(0.269)\end{array}$ & $\begin{array}{c}0.743 * * * \\
(0.208)\end{array}$ \\
\hline Germanic & & $\begin{array}{l}0.626^{*} \\
(0.372)\end{array}$ & $\begin{array}{c}0.825^{* *} \\
(0.408)\end{array}$ \\
\hline LatinAmerican & & $\begin{array}{c}1.016^{* * *} \\
(0.246)\end{array}$ & $\begin{array}{c}1.170 * * * \\
(0.277)\end{array}$ \\
\hline LatinEuropean & & $\begin{array}{l}0.462 * \\
(0.257)\end{array}$ & $\begin{array}{l}0.458^{*} \\
(0.263)\end{array}$ \\
\hline Constant & $\begin{array}{l}-11.46 \\
(7.047)\end{array}$ & $\begin{array}{l}-12.03 * \\
(6.969)\end{array}$ & $\begin{array}{l}-11.42 * \\
(6.907)\end{array}$ \\
\hline Observations & 45,421 & 45,421 & 45,421 \\
\hline Pseudo R-squared & 0.869 & 0.871 & 0.862 \\
\hline exporter fixed effects & Yes & Yes & Yes \\
\hline importer fixed effects & Yes & Yes & Yes \\
\hline time fixed effects & Yes & Yes & Yes \\
\hline
\end{tabular}

Note: Standard errors in parentheses; *** $\mathrm{p}<0.01,{ }^{* *} \mathrm{p}<0.05, * \mathrm{p}<0.1$

Source: own calculation based on Word Bank (2014a, 2014b), CEPII (2013), De Sousa (2014), La Porta et al. (1999), Filippaios and Rama (2011) and WTO (2013) databases

Table 3: PPML estimation results for wine export.

Table 4 presents the Heckman two-stage estimation using sample selection variable (export dummy variable: it is equal to 1 if the value of export is positive and 0 otherwise). As to the Heckman estimation, the first and second stage produce similar results as the empirical literature suggest: almost all coefficients are significant and have the expected signs. This is probably the most valid model, confirming previous results. However, the mill's lambdas are also significant in all models, suggesting selection bias of zero trade. It implies that zero trade flows may represent missing values instead of the absence of trade in the sample. 


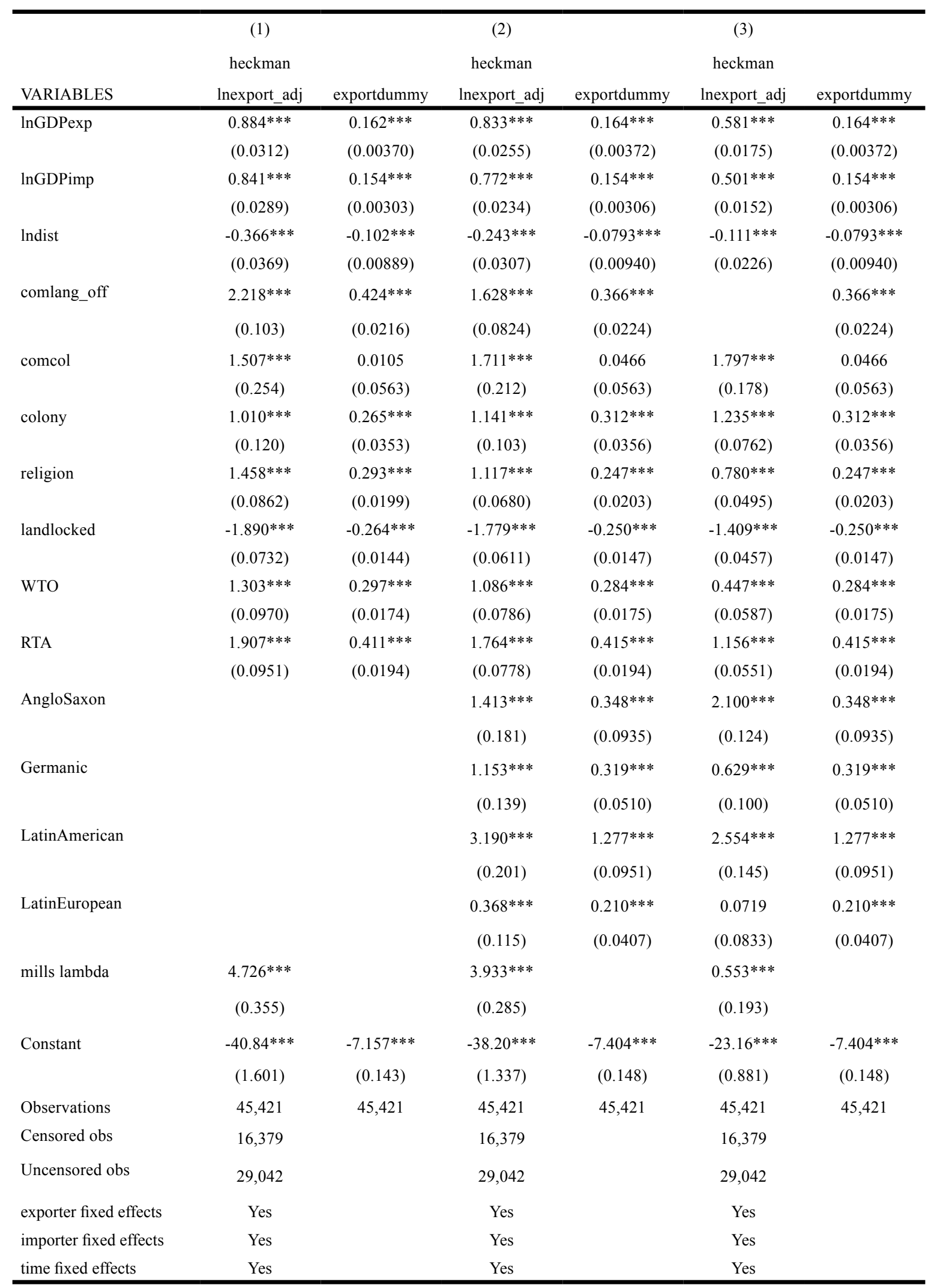

Note: to avoid dropping zero trade flows lnexport_adj was calculated by adding 1 USD to 0 trade values.

Standard errors in parentheses; $* * * \mathrm{p}<0.01, * * \mathrm{p}<0.05, * \mathrm{p}<0.1$

Source: own calculation based on Word Bank (2014a, 2014b), CEPII (2013), De Sousa (2014), La Porta et al. (1999), Filippaios and Rama (2011) and WTO (2013) databases

Table 4: Results of Heckman estimations. 
On the whole, models above validate the expected relationship between wine trade and common cultural, historical and geographical link with the trading partners. Results also confirm the positive role of free trade and regional trade agreements. In addition, the estimations suggest that Anglo-Saxon, Latin European, Latin American and Germanic countries have significant common trade relations that reduce wine trade costs. None of our hypotheses could be rejected.

\section{Conclusion}

In recent decades, global wine trade has resulted in increased wine consumption in North America and Asia. Currently, almost every second litre of wine is consumed in a third country, implying extra trade cost for countries.

The paper analysed the effects of cultural and geographical proximity on wine trade by applying a panel gravity model for global wine traders for the period of 2000-2012. It also investigated the role of language clusters in global wine trade costs.

The estimated models confirmed the standard gravity hypothesises in wine trade in line with the gravity literature (Dascal et al., 2002; Bacchetta et al., 2012; Head and Mayer, 2013; Lombardi et al., 2016).

Results suggest that the exporter and importer country's GDP, common official language and colonial history and religion based variables are positively related to wine export. It highlights the importance of country size and cultural similarity in wine export (Pinilla and Serrano, 2008; Dascal et al., 2002).

Results also suggest that costs of wine export could be lower if trading partners have common cultural relations because they know better each other's business culture and practise (Bacchetta et al., 2012; Pinilla and Serrano, 2008).

Estimations also explored a positive role of free trade agreements, i.e. lower trade barriers stimulate wine trade by reducing trade costs (Bacchetta et al., 2012; Bianco et al., 2013).

Regarding language clusters, Anglo-Saxon, Germanic and Latin American countries export wines predominantly to each other's market. The additional effects of language clusters suggest that trade effect lowering trade costs are the highest in Latin American language clusters.

In sum, our empirical evidence proves that common historical, cultural and linguistic background has a significant role in wine trade and culturally similar country groups can benefit from the most significant trade advantage.

However, note that models applied have several limitations and restrictions as usual. Wine trade data are measured at the macro level and models assumed that wine products across countries were homogenous. Further research is needed in order to take into consideration other cultural, historical and geographical factors influencing wine trade.

\section{Acknowledgements}

This research was supported by the National Research, Development and Innovation Office Project No. K_119669 'Competitiveness of Agriculture in International Trade: A Global Perspective'. We are grateful for Imre Ferto on making useful comments and suggestions on earlier versions of the paper.

Corresponding authors:

Jeremiás Máté Balogh, PhD, assistant professor

Corvinus University of Budapest, Room 222, Fövám tér 8., H-1093 Budapest, Hungary

Phone: +3630 318-6332,E-mail: jeremias.balogh@uni-corvinus.hu

ORCID:0000-0001-9081-0071

\section{References}

[1] Aizenman, J. and Brooks, E. (2008) "Globalization and taste convergence: the cases of wine and beer", Review of International Economics, Vol. 16, No. 2, pp. 217-233. ISSN 1467-9396. DOI 10.1111/j.1467-9396.2007.00659.x.

[2] Anderson, J. E. and van Wincoop, E. (2003) "Gravity with gravitas: a solution to the border puzzle", American Economic Review, Vol. 93, pp. 170-92. ISSN 0002-8282. DOI $10.1257 / 000282803321455214$. 
[3] Anderson, J. E. (1979) "A theoretical foundation for the gravity equation", American Economic Review, Vol. 69, pp. 106-116. ISSN 0002-8282.

[4] Bacchetta, M., Beverelli, C., Cadot, O., Fugazza, M., Grether, J-M., Helble, M., Nicita, A. and Piermartini R. (2012) "A practical guide to trade policy analysis", World Trade Organisation and United Nation, June 2012, Switzerland, 106 p. [Online] Available: https://www.wto.org/english/ res_e/publications_e/wto_unctad12_e.pdf [Accessed: 26 Oct. 2014].

[5] Baier, S. L. and Bergstrand, J. H. (2009) "Bonus vetus OLS: a simple method for approximating international trade-cost effects using the gravity equation", Journal of International Economics, Vol. 77, No. 1, pp. 77-85. ISSN 0022-1996. DOI 10.1016/j.jinteco.2008.10.004.

[6] Bergstrand, J. H. (1985) "The gravity equation in international trade: some microeconomic foundations and empirical evidence", The Review of Economics and Statistics, Vol. 67, No. 3, pp. 474-81. E-ISSN 15309142, ISSN 00346535. DOI 10.2307/1925976.

[7] Bergstrand, J. H. (1989) "The generalized gravity equation, monopolistic competition and the factorproportions theory in international trade", The Review of Economics and Statistics, Vol. 71, No. 1, pp. 143-53. E-ISSN 15309142, ISSN 00346535. DOI 10.2307/1928061.

[8] Cembalo, L., Caracciolo, F. and Pomarici, E. (2014) "Drinking cheaply: the demand for basic wine in Italy", Australian Journal of Agricultural and Resource Economics, Vol. 58, No. 3, pp. 374-391. ISSN 1467-8489. DOI 10.1111/1467-8489.12059.

[9] CEPII (2013) "GeoDist and Language database", Centre de recherche français dans le domaine de l'économie internationale. [Online]. Available: http://www.cepii.fr [Accessed: 10 Sep. 2014].

[10] Chaney, T. (2008) "Distorted gravity: the intensive and extensive margins of international trade", American Economic Review, Vol. 98, pp. 1707-1721. ISSN 0002-8282. DOI 10.1257/aer.98.4.1707.

[11] Dal Bianco, A., Boatto, V. L., Caracciolo, F. and Santeramo, F. G. (2015) "Tariffs and non-tariff frictions in the world wine trade", European Review of Agricultural Economics, Vol. 49, No. 1, pp. 31-57. E-ISSN 1464-3618, ISSN 0165-1587. DOI 10.1093/erae/jbv008.

[12] Dal Bianco, A., Boatto, V., Estrella-Orregob, J. and Gennari, A. (2013) "Is gravity pushing Argentinean wine exports? A gravity model applied to Argentinean wine", VDQS XX Enometrics Conference, Talca - Chile, September 2013. [Online]. Available: http://www.wineecoreports. com/Working_Papers/Abstract/WP_2013/DAL-BIANCO_ESTRELLA-ORREGO_BOATTO_ GENNARI.pdf [Accessed: 5 May 2015].

[13] Dascal, D., Mattas, K. and Tzouvelekas, V. (2002) "An Analysis of EU Wine Trade: A Gravity Model Approach International", Advances in Economic Research, Vol. 8, No. 2, pp. 135-147. E-ISSN 1573-966X, ISSN 1083-0898. DOI 10.1007/bf02295344.

[14] De Blasi, G., Seccia, A., Carlucci, D. and Santeramo, F. (2007) "Analysis of Italian High Quality Wine Exports using the Gravity Model Approach", Contributed Paper prepared for presentation at the $105^{\text {th }}$ EAAE Seminar Bologna, Italy, March 8-10, 2007. [Online]. Available: http://ageconsearch.umn.edu/bitstream/7901/1/cp070026.pdf [Accessed: 22 Jan. 2016].

[15] De Sousa, J. (2014) "International Economics Data and Programs Regional Trade Agreements". [Online]. Available: http://jdesousa.univ.free.fr/data.htm\#RegionalTradeAgreements [Accessed: 10 Jan. 2016].

[16] Eaton, J. and Kortum, S. (2002) "Technology, Geography, and Trade", Econometrica, Vol. 70, No. 5, pp. 1741-1779. E-ISSN 1468-0262. DOI 10.1111/1468-0262.00352.

[17] Filippaios, F. and Rama, R. (2011) "Cultural Distance and Internationalization: The World's Largest Food and Drink Multinationals", Agribusiness, Vol. 27, No. 4, pp. 399-419. ISSN 0742-4477. DOI 10.1002/agr.20283.

[18] Head, K. and Mayer, T. (2013) “Gravity Equations: Workhorse, Toolkit, and Cookbook", CEPII Working Paper (Centre d'études prospectives et d'informations internationales), No. 2013-27. DOI 10.1016/b978-0-444-54314-1.00003-3. 
[19] Heckman, J. (1979) "Sample selection bias as a specification error", Econometrica, Vol. 47, No. 1, pp.153-161. E-ISSN 1468-0262. DOI 10.2307/1912352.

[20] Helpman, E., Melitz, M. and Rubinstein, Y. (2008) "Estimating Trade Flows: Trading Partners and Trading Volumes", Quarterly Journal of Economics, Vol. 123, No. 2, pp. 441-487. E-ISSN 1531-4650, ISSN 0033-5533. DOI 10.1162/qjec.2008.123.2.441.

[21] Kang, H. and Fratianni M. (2006) "International Trade, OECD Membership, and Religion", Open Economies Review, Vol. 17, No. 4, pp. 493-508. E-ISSN 1573-708X, ISSN 0923-7992. DOI 10.1007/s11079-006-0361-y.

[22] Labys, W. C. and Cohen, B. C. (2004) "Trends or Cycles in Global Wine Export Shares", Division of Resource Management Working Paper RESMWP-04-03, Oenometrics XI conference VDQS-AEA, Dijion France, May 20-22. [Online]. Available: http://www.ibrarian.net/navon/paper/TRENDS OR_CYCLES_IN_GLOBAL_WINE_EXPORT_SHARES.pdf?paperid $=8089296$ [Accessed: 10 Oct. 2015].

[23] La Porta, R., Lopez-de-Silanes, F., Shleifer A. and Vishny R. (1999) "The Quality of Government", Journal of Law, Economics and Organization", Vol. 15, p. 222-279. E-ISSN 1465-7341, ISSN 8756-6222. DOI 10.3386/w6727.

[24] Linders, G. M. and de Groot, H. L. (2006) "Estimation of the gravity equation in the presence of zero flows", Tinbergen Institute, Discussion Paper 2006-072/3. DOI 10.2139/ssrn.924160.

[25] Lombardi, P., Dal Bianco A., Freda, R., Caracciolo, F. and Cembalo, L. (2016) "Development and trade competitiveness of the European wine sector: a gravity analysis of intra-EU flows", Wine Economics and Policy, Vol. 5, No. 1, pp. 50-59. ISSN 2212-9774. DOI 10.1016/j.wep.2015.12.002.

[26] Stanley, M. (2013) “The Global Wine Industry”. October 22, 2013. [Online]. Available http://blogs. reuters.com/counterparties/files/2013/10/Global-Wine-Shortage.pdf [Accessed: 22 Dec., 2015]

[27] Morrison, A. and Rabellotti, R. (2014) "Gradual catch up and enduring leadership in the global wine industry", American Association of Wine Economists, Working paper No. 148. [Online]. Available: http://www.wine-economics.org/dt_catalog/aawe-working-paper-no-148-business/

[28] Pinilla, V. and Serrano, R. (2008) "The Agricultural and Food Trade in the First Globalization: Spanish Table Wine Exports 1871 to 1935-A Case Study", Journal of Wine Economics, Vol. 3, No. 2, pp. 132-148. E-ISSN 1931-437X, ISSN 1931-4361. DOI 10.1017/s1931436100001176.

[29] Ronen, S. and Shenkar, O. (1985) "Clustering Countries on Attitudinal Dimensions: A Review and Synthesis", Academy of Management Review, Vol.10, No. 3, pp. 435-454. E-ISSN 1930-3807, ISSN 0363-7425. DOI 10.2307/258126.

[30] Santos, S. J. and Tenreyro, S. (2006) "The log of gravity", The Review of Economics and Statistics Vol. 88, pp. 641-58. E-ISSN 15309142, ISSN 00346535. DOI 10.1162/rest.88.4.641.

[31] Tinbergen, J. (1962) "An Analysis of World Trade Flows" in "Shaping the World Economy", Twentieth Century Fund, New York.

[32] Triandis, H. C. (1994) "Culture and Social Behavior", Mass McGraw Hill Custom Publishing, Boston, ISBN 0073052604.

[33] World Bank (2014a) "World Integrated Trade Solution" (WITS), Commodity Trade Database. [Online]. Available: http://wits.worldbank.org [Accessed: 15 May 2014].

[34] World Bank (2014b) "World Development Indicators" (WDI) database. [Online]. Available: http://data.worldbank.org/data-catalog/world-development-indicators [Accessed: 10 May 2014].

[35] WTO (2013) "World Trade Organisation Members and observers", [Online]. Available http://www.wto.org, [Accessed: 20 Sep. 2014]. 


\section{Appendix}

\section{Anglo-Saxon}

Australia, Canada, Hawaii (USA), Island of Man, Ireland, Netherlands Antilles, Netherlands, New Zealand, South Africa, United Kingdom, United States of America

\section{Arabic}

Algeria, Bahrain, Brunei, Egypt, Iran, Jordan, Kuwait, Lebanon, Saudi Arabia, Syria, United Arab Emirates

\section{Far East}

Bangladesh, Cambodia, China, Fiji, Guam, Hong Kong, Indonesia, Macao, Madagascar, Malawi, Malaysia, Mali, Marianas Islands, Nepal, New Caledonia, New Guinea, Papua N. Guinea, Philippines, Seychelles, Singapore, Solomon Islands, South Korea, Sri Lanka, Surinam, Tahiti, Taiwan, Thailand, Vietnam

\section{Germanic}

Austria, Belarus, Bosnia, Czech Republic, Croatia, Estonia, Germany, Hungary, Latvia, Lichtenstein, Lithuania, Luxembourg, Poland, Slovakia, Switzerland, Ukraine

\section{Independent}

Israel, India, Japan, Russia

\section{Latin American}

Argentina, Bolivia, Brazil, Chile, Colombia, Costa Rica, Cuba, Dominican Republic, Equator, Guatemala, Guyana, Honduras, Virgin Island, Jamaica, Mexico, Nicaragua, Panama, Paraguay, Peru, Puerto Rico, Santa Lucia, Salvador, Trinidad \& Tobago, Uruguay, Venezuela, Bahamas, Barbados, Bermuda, Cayman Islands.

\section{Latin European}

Albania, Belgium, Bulgaria, Cyprus, France, FYROM (Former Yugoslav Republic of Macedonia), Greece, Italy, Malta, Moldova, Monaco, Portugal, Romania, Serbia, Slovenia, Spain

\section{Near East/Africa}

Angola, Armenia, Belize, Botswana, Burundi, Cameroon, Congo, Ethiopia, Gabon, Ghana, Guinea, Ivory Coast, Kazakhstan, Kenya, Lesotho, Liberia, Morocco, Maurice, Mauritania, Mozambique, Namibia, Niger, Nigeria, Uganda, Uzbekistan, Pakistan, Reunion, Rwanda, Senegal, Sierra Leone, Soudan, Swaziland, Tanzania, Chad, Tunisia, Turkey, Yemen, Zaire, Zambia, Zimbabwe

\section{Nordic}

Denmark, Finland, Greenland, Iceland, Norway, Sweden Source: Ronen and Shenkar (1985) in Filippaios and Rama (2011)

$$
\text { Appendix 1: Language classification. }
$$




\begin{tabular}{|c|c|c|c|}
\hline Wine exporter countries & Frequency & & Frequency \\
\hline Argentina & 145 & Italy & 195 \\
\hline Australia & 171 & Lebanon & 92 \\
\hline Austria & 137 & Malta & 37 \\
\hline Argentina & 145 & Moldova & 79 \\
\hline Bulgaria & 112 & New Zealand & 123 \\
\hline Canada & 81 & Portugal & 178 \\
\hline Chile & 163 & Romania & 91 \\
\hline China & 81 & Russia & 51 \\
\hline Croatia & 71 & Slovak Republic & 56 \\
\hline Cyprus & 70 & Slovenia & 76 \\
\hline Czech Republic & 101 & South Africa & 189 \\
\hline France & 203 & Spain & 187 \\
\hline Georgia & 76 & Switzerland & 144 \\
\hline Germany & 190 & Turkey & 77 \\
\hline Greece & 115 & United Kingdom & 183 \\
\hline Hungary & 103 & United States & 157 \\
\hline
\end{tabular}

\section{List of export destinations}

Afghanistan, Albania, Algeria, Andorra, Angola, Anguilla, Antigua, and, Barbuda, Argentina, Armenia, Aruba, Australia, Austria, Azerbaijan, Bahamas, The Bahrain, Bangladesh, Barbados, Belarus, Belgium, Belize, Benin, Bermuda, Bhutan, Bolivia, Bosnia and Herzegovina, Botswana, Brazil, British, Virgin Islands, Brunei, Bulgaria, Burkina, Faso, Burundi, Cambodia, Cameroon, Canada, Cape, Verde, Cayman, Islands, Central, African, Republic, Chad, Chile, China, Christmas Island, Cocos (Keeling) Islands, Colombia, Comoros, Congo Dem. Rep., Congo Rep., Cook Islands, Costa, Rica, Cote d'Ivoire, Croatia, Cuba, Cyprus, Czech Republic, Denmark, Djibouti, Dominica, Dominican Republic, East Timor, Ecuador, Egypt Arab Rep., El Salvador, Equatorial Guinea, Eritrea, Estonia, Ethiopia(excludes Eritrea), Faeroe Islands, Falkland Island, Fiji, Finland, Sudan, France, French Polynesia, Gabon, Gambia, Georgia, Germany, Ghana, Gibraltar, Greece, Greenland, Grenada, Guatemala, Guinea, Guinea-Bissau, Guyana, Haiti, Honduras, Hong Kong, China, Hungary, Iceland, India, Indonesia, Iran, Islamic Rep., Iraq, Ireland, Israel, Italy, Jamaica, Japan, Jordan, Kazakhstan, Kenya, Kiribati, Korea, Dem. Rep., Korea, Rep., Kuwait, Kyrgyz Republic, Lao PDR, Latvia, Lebanon, Lesotho, Liberia, Libya, Lithuania, Luxembourg, Macao, Macedonia FYR, Madagascar, Malawi, Malaysia, Maldives, Mali, Malta, Marshall Islands, Mauritania, Mauritius, Mexico, Micronesia, Fed. States, Moldova, Mongolia, Montserrat, Morocco, Mozambique, Myanmar, Namibia, Nauru, Nepal, Netherlands, Netherlands Antilles, New Caledonia, New Zealand, Nicaragua, Niger, Nigeria, Niue, Norfolk Island, Northern Mariana Islands, Norway, Oman, Pakistan, Palau, Panama, Papua, New Guinea, Paraguay, Peru, Philippines, Pitcairn, Poland, Portugal, Qatar, Romania, Russian Federation, Rwanda, Saint Helena, Saint Pierre and Miquelon, Samoa, San Marino, Sao Tome and Principe, Saudi, Arabia, Senegal, Seychelles, Sierra, Leone, Singapore, Slovak Republic, Slovenia, Solomon Islands, Somalia, South Africa, Spain, Sri Lanka, St. Kitts and Nevis, St. Lucia, Vincent and the Grenadines, Suriname, Swaziland, Sweden, Switzerland, Syrian Arab Republic, Tajikistan, Tanzania, Thailand, Togo, Tokelau, Tonga, Trinidad and Tobago, Tunisia, Turkey, Turkmenistan, Turks and Caicos Isl., Tuvalu, Uganda, Ukraine, United Arab Emirates, United Kingdom, United States, Uruguay, Uzbekistan, Vanuatu, Venezuela, Vietnam, Wallis and Futuna Islands, Yemen, Zambia, Zimbabwe

Source: own composition based on sample data

Appendix 2: Pattern of database. 